\title{
A NEW TECHNIQUE IN EXCHANGE TRANSFUSION
}

\author{
BY \\ TREVOR WRIGHT \\ From St. George's Hospital, Lincoln
}

(RECEIVED FOR PUBLICATION JANUARY 23, 1961)

In experienced hands exchange transfusion carries a very low operative risk. Nevertheless, infants who are initially very anaemic present a grave problem as this treatment is their only hope of survival. There are also other infants who appear well at the start of the transfusion, but become ill or die during the procedure.

Walker and Neligan (1955) discussed these problems and listed the probable factors involved as heart failure, shock and possibly biochemical changes. Campbell (1955) considered that deterioration during exchange transfusion was in many cases probably due to electrolyte disturbance, mainly hyperkalaemia. He noted, however, that in two infants having similarly high levels of serum potassium, one was ill and one quite well. Farquhar and Smith (1958) stated that 'changes in serum electrolytes were shared by infants who were disturbed and by those who showed no abnormality'. In a series of 18 consecutive cases of haemolytic disease studied in this hospital during 1958-59, serum electrolyte estimations and simultaneous electrocardiograph tracings were done at every $100 \mathrm{ml}$. during the exchange. There was no correlation between deterioration of the infant's condition observed clinically and the serum level of either calcium or potassium, and not a single electrocardiogram showed any evidence of electrolyte disturbance. Even when donor blood with a potassium level of $19.2 \mathrm{mEq} /$ litre was used in one case there was no clinical distress, and the infant's serum potassium and electrocardiogram remained normal.

It has been my impression that with increasing experience and our present method of using packed donor cells, disturbances due to hyperkalaemia and hypocalcaemia play a decreasing role. I agree with O'Neill and Gordon (1959) that cardiac embarrassment is a more frequent cause of clinical distress. This may occur not only in infants who are already very anaemic and ill, but also during the exchange in an otherwise well baby. This paper attempts to assess the value of venous pressure measurements in the umbilical catheter during exchange transfusion and control of the speed of transfusion in relation to cardiac failure.

\section{Criteria}

The criteria for exchange transfusion were those recommended by Lathe, Claireaux and Norman (1958), the main factors being a cord haemoglobin below $15.5 \mathrm{~g} . / 100 \mathrm{ml}$. or a cord bilirubin of $5 \mathrm{mg}$./ $100 \mathrm{ml}$. or more, with a second exchange being indicated if the serum bilirubin reached $20 \mathrm{mg}$./ $100 \mathrm{ml}$. before the fifth day.

\section{Method}

The method employed was to measure in centimetres and record the height of the column of blood in the umbilical catheter, above the level of the sternal manubrium. Such measurements were made before the exchange transfusion, and during the procedure immediately after the injection of each $100 \mathrm{ml}$. of blood. The total time taken to complete the transfusion was noted, and a continuous record of the clinical status of the patient was made.

\section{Material}

The material upon which the recorded observations were made consisted of 15 consecutive exchange transfusions carried out as part of the routine work of the Paediatric Department during 1959-60. In addition there were three transfusions in which observations were recorded; they have not been included in this paper because of incomplete exchange transfusions (less than $60 \mathrm{ml}$. per lb. body weight) due to technical difficulties. Follow-up of these three infants over six months has shown them to be physically and mentally normal.

All the exchange transfusions were performed for the treatment of haemolytic disease of the newborn and none were carried out on premature babies without haemolytic disease. Three infants required two, and one infant three exchange transfusions; a single transfusion was sufficient in the other six babies.

\section{Technique}

The apparatus is that normally employed for exchange transfusion with one simple addition. The umbilical catheter used is made of 'portex'* tubing of $2.0 \mathrm{~mm}$. bore, with a length of similar tubing joined to it at right angles

* Portex T Tubing manufactured by Portland Plastics, Hythe, Kent. 
in an inverted $\mathrm{T}$-shaped fashion (see Figure). The internal junction between the two arms of the $T$ was made exact, with smooth even surfaces (to prevent blood clot forming). There was some initial difficulty about this detail, but the manufacturers overcame this.

The upright arm of the catheter is held perpendicular by threading a piece of silk through its upper open end, and looping this over a suitable support. The umbilical end of the catheter is then inserted into the umbilical vein. Blood is allowed to flow, or is withdrawn, as far as the $T$ junction, when it enters the perpendicular arm. This should then be clamped with artery forceps at a distance of 20 or $30 \mathrm{~cm}$. from the $\mathrm{T}$ junction (to avoid the area of venous pressure measurements) and further blood withdrawn into the syringe in the normal manner. When all the apparatus has been 'filled' with blood, the clamp may be removed. When the baby is at rest the height of the column of blood above the level of the sternal manubrium is measured (in centimetres) in the vertical arm of the catheter (umbilical venous pressure).

The apparatus is rinsed through with silicone solution before sterilization. Clotting in the vertical part of the catheter can be completely avoided by rinsing with sterile normal saline at every $100 \mathrm{ml}$. blood exchanged. This can easily be done without removing the catheter from the umbilical vein, by simply pinching it (between finger and thumb) on the umbilical side of the $\mathrm{T}$ junction, while rinsing is taking place. Heparin solution for rinsing is not necessary.

The horizontal limb of the catheter measures $60 \mathrm{~cm}$., and the volume contained within this is $1.75 \mathrm{ml}$. As will be seen from the recorded data, the venous pressure recorded in the vertical limb of the catheter was most frequently $12 \mathrm{~cm}$. or less. This means an increase in volume of the 'dead space' (extra to the usual form of apparatus) in the order of $0.35 \mathrm{ml}$. We do not consider this makes any significant difference to the efficiency of the exchange.

During treatment of the previously mentioned 19 cases in 1958-59, and in the early cases of this series of 10 cases, it was realized that most infants were without distress when the venous pressure measured no more than $12 \mathrm{~cm}$. This figure was therefore accepted as the pressure at which blood may be injected without causing cardiac embarrassment. The upright limb of the $T$ tube was therefore marked at a height of $12 \mathrm{~cm}$. While injecting blood during the exchange this height was not exceeded, except when the baby cried or became restless; when this occurs it is wise to call a temporary halt. This technique was found to be a ready means of controlling the 'injection pressure' or speed of injection.

The minimum staff necessary for the procedure has been two doctors and one experienced nursing sister. With this degree of supervision no special snags have been encountered. The simple manipulations listed above may appear cumbersome when expressed on paper, but in practice are quite quickly carried out. They may also serve to keep the team 'on their toes' during what may (in a large baby) become a somewhat prolonged and tiring operation.

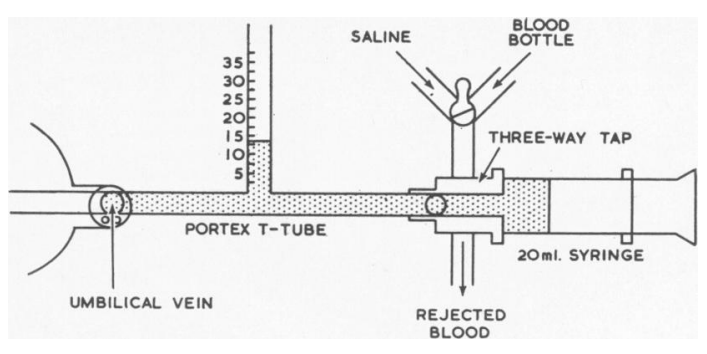

FIG. Exchange transfusion apparatus.

\section{Results}

At all times, except where expressly stated, the measurement of venous pressure in centimetres was recorded with the baby at rest. A 'glucose teat' was sometimes necessary as a 'comforter'.

Venous pressure before exchange varied from 3.5 to $19 \mathrm{~cm}$. in the 10 infants. The maximum venous pressure recorded during transfusion was $25 \mathrm{~cm}$.

The venous pressure at the conclusion of transfusion varied between 1.0 and $12 \mathrm{~cm}$.

With the exception of Cases 2 and 6, which will be referred to later, all the infants were reasonably well clinically at the start of the procedure. The highest pre-transfusion venous pressure recorded in these eight children was $11 \mathrm{~cm}$.

In the seven cases (nine exchange transfusions) who were well throughout the transfusion, all, except Case 5 (transfusion No. 8), had a maximum venous pressure of $12 \mathrm{~cm}$. or less. In transfusion No. 8 one recording of $17 \mathrm{~cm}$. was made, and all the others were between 10.5 and $12.5 \mathrm{~cm}$.

In Case 2 (transfusion No. 3), weight $6 \mathrm{lb}$,, serum bilirubin $18.2 \mathrm{mg}$. per $100 \mathrm{ml}$., the highest venous pressure before exchange was $19 \mathrm{~cm}$. This infant was moderately cyanosed with increasingly laboured respiration: $20 \mathrm{ml}$. of blood were withdrawn at the beginning of the exchange, reducing the pressure to $3.2 \mathrm{~cm}$., with marked clinical improvement and disappearance of cyanosis. During the exchange in this case the venous pressure rose to a maximum value of $25 \mathrm{~cm}$.

In Case 7 (transfusion No. 10), weight 10 lb. 5 oz., cord bilirubin $5.0 \mathrm{mg}$. per $100 \mathrm{ml}$, the venous pressure before exchange was $3.5 \mathrm{~cm}$. This infant was clinically very fit. It was decided to exchange at a speed which would previously have been regarded as safe $(8.0 \mathrm{ml} . /$ minute $)$, and it was noted that during injection the column of blood in the vertical arm of the $T$ tube measured $36 \mathrm{~cm}$. When injection was slowed down to what would have been regarded as very slow $(5.0 \mathrm{ml} . /$ minute $)$ the measurement was $19 \mathrm{~cm}$. 
TABLE

\begin{tabular}{|c|c|c|c|c|c|c|}
\hline $\begin{array}{l}\text { Case } \\
\text { No. }\end{array}$ & $\begin{array}{l}\text { Exchange } \\
\text { Transfusion } \\
\text { No. }\end{array}$ & $\begin{array}{c}\text { Venous } \\
\text { Pressure } \\
\text { Before } \\
\text { Exchange } \\
\text { (cm.) }\end{array}$ & $\begin{array}{c}\text { Maximum } \\
\text { Venous } \\
\text { Pressure } \\
\text { During } \\
\text { Exchange } \\
\text { (cm.) }\end{array}$ & $\begin{array}{c}\text { Venous } \\
\text { Pressure } \\
\text { End of } \\
\text { Exchange } \\
(\mathrm{cm} .)\end{array}$ & Clinical State During Exchange & Follow-up \\
\hline 1 & 1 & $5 \cdot 0$ & $12 \cdot 0$ & $9 \cdot 5$ & Satisfactory & \multirow{10}{*}{$\begin{array}{l}\text { All alive } \\
\text { and } \\
\text { mentally } \\
\text { and } \\
\text { physically } \\
\text { normal }\end{array}$} \\
\hline 2 & $\left\{\begin{array}{l}2 \\
3\end{array}\right.$ & $\begin{array}{r}2 \cdot 0 \\
19 \cdot 0\end{array}$ & $\begin{array}{l}15 \cdot 0 \\
25 \cdot 0\end{array}$ & $\begin{array}{l}1 \cdot 0 \\
6 \cdot 5\end{array}$ & $\begin{array}{l}\text { Very ill at start; oxygen required } \\
\text { Second exchange, ill at start, oxygen required }\end{array}$ & \\
\hline 3 & $\left\{\begin{array}{l}4 \\
5\end{array}\right.$ & $\begin{array}{l}5 \cdot 5 \\
9 \cdot 0\end{array}$ & $\begin{array}{l}5 \cdot 5 \\
9 \cdot 0\end{array}$ & $\begin{array}{l}1 \cdot 0 \\
7 \cdot 5\end{array}$ & $\begin{array}{l}\text { Satisfactory } \\
\text { Satisfactory }\end{array}$ & \\
\hline 4 & 6 & $4 \cdot 2$ & $6 \cdot 0$ & $6 \cdot 0$ & Good at start; oxygen needed at end & \\
\hline 5 & $\left\{\begin{array}{l}7 \\
8\end{array}\right.$ & $\begin{array}{r}1 \cdot 0 \\
10 \cdot 0\end{array}$ & $\begin{array}{r}6 \cdot 5 \\
17 \cdot 0\end{array}$ & $\begin{array}{r}2 \cdot 0 \\
10 \cdot 5\end{array}$ & $\begin{array}{l}\text { Fair at start, mild cyanosis later; oxygen given } \\
\text { Excellent }\end{array}$ & \\
\hline 6 & 9 & $5 \cdot 8$ & $4 \cdot 0$ & $1 \cdot 5$ & Ill, vomiting, suction required & \\
\hline 7 & 10 & $3 \cdot 5$ & $12 \cdot 0$ & $12 \cdot 0$ & Satisfactory & \\
\hline 8 & $\left\{\begin{array}{l}11 \\
12 \\
13\end{array}\right.$ & $\begin{array}{r}8 \cdot 0 \\
5 \cdot 5 \\
11 \cdot 0\end{array}$ & $\begin{array}{r}10 \cdot 0 \\
7 \cdot 0 \\
10 \cdot 0\end{array}$ & $\begin{array}{l}3 \cdot 5 \\
4 \cdot 0 \\
5 \cdot 5\end{array}$ & $\begin{array}{l}\text { Occasional oxygen required } \\
\text { Satisfactory } \\
\text { Satisfactory }\end{array}$ & \\
\hline 9 & 14 & $2 \cdot 5$ & $5 \cdot 0$ & $5 \cdot 0$ & Very well & \\
\hline 10 & 15 & $7 \cdot 0$ & $8 \cdot 0$ & $4 \cdot 5$ & Very well & \\
\hline
\end{tabular}

Case 1 was also clinically fit, weight $6 \frac{1}{2} \mathrm{lb}$., cord haemoglobin $110 \%$ and bilirubin $6 \mathrm{mg}$. per $100 \mathrm{ml}$. An exchange of $80 \mathrm{ml}$./lb. was completed in 90 minutes, i.e. $5.8 \mathrm{ml}$. blood exchanged per minute. The venous pressure before exchange was $5 \mathrm{~cm}$., the maximum $12 \mathrm{~cm}$. and the final $9 \cdot 5 \mathrm{~cm}$.

Cases 2 and 6 were the most severely affected of the 10 infants, and were in the class referred to as 'prehydropic' by O'Neill and Gordon (1959).

In Case 6 (transfusion No. 9), weight 7 lb. $4 \frac{1}{2}$ oz., cord haemoglobin $36 \%$ and bilirubin $6.7 \mathrm{mg}$. per $100 \mathrm{ml}$., an $80 \mathrm{ml} . / \mathrm{lb}$. exchange was completed in 150 minutes, i.e. $3.8 \mathrm{ml}$. of blood exchanged per minute. The venous pressure before transfusion was $5.8 \mathrm{~cm}$., maximum during the procedure was $4 \mathrm{~cm}$., and the final pressure was $1.5 \mathrm{~cm}$.

In Case 2 (transfusion No. 2) the infant was very ill and the cord blood figures of haemoglobin $27 \%$ and bilirubin $5.3 \mathrm{mg}$. per $100 \mathrm{ml}$., are the worst, in combination, that have been encountered so far in this hospital. A $60 \mathrm{ml}$./lb. exchange was completed in 105 minutes, i.e. $3.5 \mathrm{ml}$. blood exchanged per minute. It was considered imprudent to attempt an $80 \mathrm{ml} . / \mathrm{lb}$. exchange in this infant. Venous pressure before exchange was $2 \mathrm{~cm}$., maximum $15 \mathrm{~cm}$., and final $1.0 \mathrm{~cm}$. The low initial figure is due to the fact that there had been blood loss after the cord was cut and this is therefore not a true pre-transfusion record. The results of the $\mathbf{1 0}$ cases are summarized in the Table.

\section{Discussion}

Although $+4.0 \mathrm{~cm}$. (Mollison, 1956) is regarded as the normal figure, in the cases under discussion there were no clinical signs of distress in those infants in whom the venous pressure measured $12 \mathrm{~cm}$. or less. As illustrated in a well baby (Case 1) a resting venous pressure of this order will not be exceeded by a speed of exchange between 5 and 6. ml./minute. In Case 7 in which a speed of exchange up to $8 \mathrm{ml}$./min. was employed for a short period the recorded measurements confirm my previous impressions that a rapid injection of blood can elevate the venous pressure (during injection) to a dangerously high level. In an ill baby in whom the resting venous pressure is already high there would be the distinct possibility of cardiac embarrassment.

In Cases 2 and 6, because of their extremely precarious clinical condition, special precautions were taken to keep the 'injection pressure' below $12 \mathrm{~cm}$. throughout the transfusion. This resulted in a very slow speed of injection of 3.5 to 4.0 $\mathrm{ml} . / \mathrm{min}$., with obvious benefit to the infants, as the exchange transfusions were completed successfully, and in a six months' follow-up both infants remained physically and mentally normal.

At the completion of an exchange transfusion it is tempting in some cases to add a further 10 or $20 \mathrm{ml}$. of blood to finish with a higher haemoglobin level. In Case 7, although a well baby, an extra $10 \mathrm{ml}$. of blood injected at the conclusion of the exchange 
raised the resting venous pressure from 7 to $12 \mathrm{~cm}$. In an ill baby such a procedure could be disastrous. It is preferable to increase the haemoglobin by an extended slow transfusion of 20 to $30 \mathrm{ml}$. as a follow on (O'Neill and Gordon, 1959), or to give a small 'top-up' scalp vein transfusion at a later date.

A resting pressure lower than $4 \mathrm{~cm}$. may indicate a seriously ill infant. This may arise if the venous pressure is high, for when the cord is cut, blood will immediately spurt out; if the umbilical vein has not been instantly catheterized the rapid loss of blood will have the effect of lowering the venous pressure before measurement has been possible. This happened in Case 2 (transfusion No. 2) where the venous pressure before transfusion was only $2.0 \mathrm{~cm}$., and was undoubtedly a false reading. An initial venous pressure below $3.0 \mathrm{~cm}$. may indicate a weak myocardium and should suggest caution.

\section{Conclusion}

Venous pressure was measured in the umbilical vein and recorded during exchange transfusion in 10 consecutive cases of haemolytic disease of the newborn.

In the eight infants who were clinically fair before transfusion the maximum venous pressure was $11 \mathrm{~cm}$.
In those seven infants who remained without distress during the exchange transfusion the maximum venous pressure was about $12 \mathrm{~cm}$.

With the use of a 'portex' $T$ tube an 'injection pressure' of $12 \mathrm{~cm}$. can be maintained throughout the procedure, thus limiting the speed of injection and avoiding cardiac overloading. The latter is the most frequent cause of distress, especially in the ill anaemic baby. The technique described is considered to be a useful method of treatment, especially in this type of patient.

It is with great pleasure that I record my thanks to Sister B. M. Barchard, Miss S. A. Broadley and Drs. T. Woodward, B. Weir and D. H. Livingston for their assistance with the transfusions and preparation of this paper, and also to Professor R. S. Illingworth and Dr. K. Holt for their helpful criticism.

\section{REFERENCES}

Campbell, W. A. B. (1955). Potassium levels in exchange transfusion. Arch. Dis. Childh., 30, 513.

Farquhar, J. W. and Smith, H. (1958). Clinical and biochemical changes during exchange transfusion. Ibid., 33, 142.

Lathe, G. H., Claireaux, A. E. and Norman, A. P. (1958). Recent Advances in Paediatrics, ed. D. Gairdner, 2nd ed., p. 115. Churchill, London.

Mollison, P. L. (1956). Blood Transfusion in Clinical Medicine, 2nd ed., p. 502 . Blackwell, Oxford.

O'Neill, E. M. and Gordon, R. R. (1959). Extended exchange transfusion in pre-hydropic infants. Arch. Dis. Childh., 34, 174.

Walker, W. and Neligan, G. A. (1955). Exchange transfusion in haemolytic disease of the newborn. Brit. med. J., 1, 681 . 